\title{
Cellulose Powder from Piper nigrum L. Agro-Industrial Waste: Effect of Preparation Condition on Chemical Structure and Thermal Degradation
}

(Serbuk Selulosa daripada Sisa Agro-Industri Piper nigrum L.: Kesan Keadaan Penyediaan terhadap Struktur Kimia dan Degradasi Terma)

\author{
Ain Nadiah Sofiah Ahmad Khorairi, Noor Soffalina Sofian-SenG*, Rizafizah Othaman \& KHAirul \\ FARIHAN KASIM
}

\begin{abstract}
White pepper is generally produced via water retting process to decorticate the pericarp of green pepper. The decorticated pericarp is considered as an agro-industrial waste and environmental pollutant as many farmers still discard the waste into the rivers. These wastes majorly contain cellulose, hemicellulose, pectin, and other organic compound. Cellulose was obtained from alkaline treatment (4 wt. \% sodium hydroxides, NaOH) followed by bleaching process. This study reports the effect of soaking cycle in bleaching treatment on the chemical structure and thermal degradation of cellulose. The cellulose obtained from pepper (Piper nigrum L.) pericarp waste were characterised by colour analysis, Fourier transform infrared spectroscopy (FTIR) and thermogravimetric analysis (TGA). Increased number of bleaching cycles produced a whiter colour and high thermal stability of cellulose powder. The whiteness index (WI) for high bleaching cycle sample was found significantly high $(p<0.05)$ with the value of $77.00 \pm 1.10$. Thermal analysis indicates a derivative thermogravimetric analysis (DTG) peak at $332{ }^{\circ} \mathrm{C}$. The FTIR spectrum proven that the condition of bleaching treatment changes the absorption intensity at bands 1732, 1540, and $1460 \mathrm{~cm}^{-1}$ which due to the loss of hemicellulose and lignin. The use of pepper pericarp waste that is usually discarded may provide a sustainable alternative for the production of cellulose.
\end{abstract}

Keywords: Agro-industrial waste; cellulose; white pepper pericarp

ABSTRAK

Umumnya lada putih dihasilkan melalui proses perendaman air untuk menanggalkan perikarp luar lada hijau. Kulit lada yang ditanggalkan merupakan sisa agro-industri dan bahan pencemar kerana kebanyakan petani masih membuangnya ke dalam sungai. Sisa ini mengandungi selulosa secara majoritinya, berserta hemiselulosa, pektin dan sebatian organik. Selulosa boleh diperoleh melalui kaedah alkali (4 bt. \% larutan natrium hidroksida, NaOH) dan pelunturan. Kajian ini bertujuan untuk melaporkan kesan kitaran rendaman dalam rawatan pelunturan terhadap struktur kimia dan degradasi termal selulosa. Selulosa yang diperoleh daripada sisa perikarp lada (Piper nigrum L.) dicirikan dengan menggunakan analisis warna, Fourier spektroskopi inframerah (FTIR) dan analisis termogravimetrik (TGA). Peningkatan jumlah kitaran rawatan pelunturan, menghasilkan selulosa kulit lada yang lebih putih dan tinggi kestabilan termal. Indeks keputihan (WI) bagi sampel dengan jumlah kitaran rawatan pelunturan yang tinggi, dilihat meningkat secara signifikan $(p<0.05)$ dengan nilai $77.00 \pm 1.10$. Analisis terma menunjukkan puncak terbitan analisis termogravimetrik (DTG) pada suhu $332{ }^{\circ} \mathrm{C}$. Spektrum FTIR membuktikan keadaan penyediaan rawatan pelunturan mengubah keamatan jalur 1732, 1540 dan $1460 \mathrm{~cm}^{-1}$ kerana kehilangan hemiselulosa dan lignin. Penggunaan sisa perikarp lada yang biasanya dibuang mungkin dapat memberi alternatif dalam menghasilkan selulosa bagi kegunaan industri lain.

Kata kunci: Perikarp lada putih; selulosa; sisa agro-industri

\section{INTRODUCTION}

Agro-industrial activities have produced vast amount of waste each year. Bharathiraja et al. (2017) reported that roughly 5 billion metric tons of agro-industrial by-product such as rice bran and straw, sugarcane bagasse, fruits, and vegetable wastes were discarded annually. The pile up of these residues, does not only cause negative impact to the environment but also a loss of potential material. This is because in general, agro-industrial waste composed of lignocellulosic material such as cellulose, hemicellulose, lignin, and ashes (Kalia et al. 2011; Mussatto et al. 2012; Rosa et al. 2010). Most of these wastes have been 
researched to be used as renewable resource of cellulosic materials as it is cheaper and the cellulose from plant's wall is easier to be extracted than from wood source (Alemdar \& Sain 2008; Jonoobi et al. 2015).

Production of high purity cellulose commonly involved alkali and chlorite bleaching treatment (Bhandari et al. 2013). The purpose of alkali treatment is to solubilise hemicellulose and lignin (Johar et al. 2012). Nevertheless, a single alkalisation process is unable to remove all the remaining lignin and hemicellulose, hence bleaching treatment is often used. Other than enhancing the whiteness of cellulose fiber, bleaching helps in producing smaller size with better uniformity of cellulose (Johar et al. 2012; Rosa et al. 2010). Recently, the production of cellulose from various sources of agro waste materials has been extensively studied, which include rice husk (Fathi et al. 2018), onion and garlic skins (Reddy \& Rhim 2018), pomelo albedo (Zain et al. 2014) and mango seed (Henrique et al. 2013). However, there is no study conducted in extracting the cellulose from pepper pericarp waste.

Pepper (Piper nigrum L.) is one of the most important spices in history. Malaysia is currently ranked as the 5th pepper producer in the world (Kamarulzaman et al. 2013). White pepper has a lighter color, milder flavor and pungency compared to black pepper (Sephton 2011). The production of white pepper usually involved water retting process in rivers or natural water bodies to remove its outer pericarp (Bunchol 2011). This pericarp is considered as agro-industrial waste of white pepper as it is a customary practice to discard it directly into the rivers without proper waste treatment.

Thus, this study aims to extract cellulose from pepper pericarp waste and investigate the effect of various bleaching conditions on the cellulose obtained. The changes of physical and chemical composition were evaluated through colour analysis, FTIR, and TGA.

\section{MATERIALS AND METHODS}

Green pepper berries (Piper nigrum L.) was collected from Herba Bagus farm in Kluang (Johor, Malaysia). Sodium hydroxide (99\% purity, QREC Sdn Bhd), sodium chlorite (Sigma-Aldrich) and acetic acid glacial (Friendemann Schmidt) were used for the extraction of cellulose. All the reagent grade chemicals were used without further purification.

\section{RAW MATERIAL PREPARATION}

The green pepper berries were cleaned and washed with water to remove impurities and dirt. The pepper was soaked in a conical flask containing water at ratio of 1 : 2 (pepper: distilled water, w/v). The flasks were placed in a water bath shaker for 8 days at $28{ }^{\circ} \mathrm{C}$. The soften pepper pericarp was peeled manually and dried overnight in a convection oven (Protech, Malaysia) at $40^{\circ} \mathrm{C}$ until constant weight was obtained. Dried sample was then grinded and sieved.

\section{ALKALINE TREATMENT}

The alkaline and bleaching process was conducted according to Johar et al. (2012) with some modification. The powdered pepper pericarp was transferred into a round bottom flask and treated with an alkali solution (4 wt. $\% \mathrm{NaOH}$ ). The treatment was carried out under reflux condition at $80-90{ }^{\circ} \mathrm{C}$ for $3 \mathrm{~h}$. The solid was then filtered and washed with water. After washing, the alkaline treatment was repeated three more times.

\section{BLEACHING TREATMENT}

Following alkaline treatment, the bleaching process was performed by using $1.7 \% \mathrm{NaClO}_{2}$, acetic buffer and distilled water in reflux environment for $4 \mathrm{~h}$ at $80-90{ }^{\circ} \mathrm{C}$. The mixture was filtered and washed with water. The bleaching treatment was carried out in four cycles (1C, 2C, 3C and 4C) to extract cellulose from pepper pericarp. Sample $1 \mathrm{C}$ undergo only one bleaching treatment while sample $2 \mathrm{C}, 3 \mathrm{C}$, and $4 \mathrm{C}$ subjected to bleaching treatment for 2,3 , and 4 times, respectively.

\section{CHARACTERISATION}

\section{COLOUR ANALYSIS}

The colour of untreated, alkali-treated and bleached were determined by Minolta colorimeter (Chroma meter CR 400, Japan) with a Hunter Lab color system (L*, a*, and $\left.b^{*}\right)$. The whiteness value was measured based on Color iMatch Color Calculations Guide (2012) formula, WIhunter $=\mathrm{L}-3 \mathrm{~b}$. The optical microscopy of pepper pericarp at different stages of treatment was observed by an optical stereo microscope (Leica EZ4) and captured with 16-megapixel (MP) camera (Huawei Nova 3e, China).

\section{FOURIER TRANSFORM INFRARED (FTIR) SPECTROSCOPY ANALYSIS}

The FTIR spectrum of cellulose was recorded by using PerkinElmer attenuated total reflection (ATRFTIR) spectrometer. The results were measured in the wavelength range from $400-4000 \mathrm{~cm}^{-1}$, with a resolution of $4 \mathrm{~cm}^{-1}$ and four scans were averaged for each sample (Zain et al. 2014). Samples before and after each alkali and bleaching $(1 \mathrm{C}, 2 \mathrm{C}, 3 \mathrm{C}$ and $4 \mathrm{C})$ treatment were analysed to observed changes in the functional group.

\section{THERMOGRAVIMETRIC ANALYSIS (TGA)}

The thermal stability of each sample was measured by using Mettler Toledo thermogravimetric analyser (TGA/ SDTA 85-F). All samples were heated from 25 to 600 ${ }^{\circ} \mathrm{C}$ under nitrogen gas flow of $10{ }^{\circ} \mathrm{C} \mathrm{min}^{-1}$ (Mohd et al. 2016). 


\section{STATISTICAL ANALYSIS}

All experiments were performed in three replications. The data for colour analysis were performed in triplicate. The results were expressed in mean \pm standard deviation. The data was analysed using analysis of variance test (ANOVA) and Duncan's multiple range test (DMRT) by using IBM SPSS Statistic Software version 20. Means are significantly different when $(\mathrm{p}<0.05)$.

\section{RESULTS AND DISCUSSION}

Visualisation via optical microscopy of the pepper pericarp changes after each treatment are as displayed in Figures 1 and 2. The original brown colour of untreated pepper pericarp changes to lighter brown after alkaline treatment and started to fade after bleaching. These images indicate effective removal of lignin, hemicellulose and other non-cellulosic materials. Sample 4C which has been subjected to four cycle of bleaching process has whiter colour of cellulose as compared to another bleached sample (1C, 2C, \& 3C). The number of cycles in bleaching treatment was observed to play an important role in the removal of lignin. Table 1 shows the whiteness index of untreated pepper pericarp, alkali treated and all bleached samples (1C, 2C, 3C \& $4 \mathrm{C})$. As the bleaching cycle increased, the whiteness of each sample significantly increased $(p<0.05)$. The bleached samples illustrate improvements in whiteness index. Bleached sample with 4 cycle of treatment was measured to have the highest whiteness index as compare to untreated, alkali treated and other low bleached treated samples with the value of $77.00 \pm 1.10,16.36 \pm 0.74$, $-4.30 \pm 1.11,-8.93 \pm 0.52,46.05 \pm 0.92$, and $70.39 \pm 0.94$, respectively.

\section{FTIR CHARACTERISATION}

The FTIR spectrums of untreated pepper pericarp, alkali treated and bleached sample (1C, 2C, 3C \& 4C) are presented in Figure 3. The absorption peak at 3400$3300 \mathrm{~cm}^{-1}$ and 2900-2890 $\mathrm{cm}^{-1}$ was observed in all samples, which indicate the presence of $\mathrm{O}-\mathrm{H}$ groups and $\mathrm{C}-\mathrm{H}$ groups, respectively, in cellulose fibres (Ngadi \& Lani 2014; Yin et al. 2015). The peak around $1734 \mathrm{~cm}^{-1}$ was highly visible in raw pepper pericarp spectrum. It represents the $\mathrm{C}=\mathrm{O}$ of the acetyl and ester groups in pectin, hemicellulose and lignin (Phanthong et al. 2015). Comparison between samples 1C, 2C, $3 \mathrm{C}$, and $4 \mathrm{C}$ showed how the intensity of this peak decreased and as the bleaching treatment prolonged with each additional cycle, depicting larger amount of non-cellulosic materials in pepper pericarp are being removed. The disappearance of peak around 1509-1609 $\mathrm{cm}^{-1}$ (aromatic $\mathrm{C}=\mathrm{C}$ in lignin) indicated successful removal of remaining lignin as it was only found in pepper pericarp and alkali treated sample (Mandal \& Chakrabarty 2011). The region of absorbance peak at $1460 \mathrm{~cm}^{-1}$ corresponding to group of $-\mathrm{CH}_{2}$ and/or $-\mathrm{C}=\mathrm{C}$ stretching in aromatic group of lignin and hemicellulose (Jonoobi et al. 2009). This peak started to disappear with the increasing number of bleaching cycles which proven to remove most of the hemicellulose and lignin from the pepper pericarp. The absorption peak at 1155 and 1029 $\mathrm{cm}^{-1}$ which were observed in all samples refer to $-\mathrm{COC}$ group due to anti-symmetrical deformation in cellulose (Silva et al. 2008) and aromatic ring of surface cellulose fibre (Karimi et al. 2014). Whereas the band around 895 $\mathrm{cm}^{-1}$ was attributed to the glycosidic $\mathrm{C}-\mathrm{H}$ rock vibration that indicates the typical structure of cellulose.

\section{THERMOGRAVIMETRIC ANALYSIS}

Figure 4 shows the thermogravimetric weight loss and DTG of samples before and after bleaching for 1, 2, 3, and 4 cycles. The results in Figure 4(a) exhibited the weight loss of all samples primarily take place between $25-600{ }^{\circ} \mathrm{C}$. Untreated pepper pericarp and all bleached samples started to have first weight loss at a temperature below than $100{ }^{\circ} \mathrm{C}$. This initial change is due to water evaporation which was highly influenced by the moisture content of the sample (Ilyas et al. 2018). The degradation of hemicellulose and lignin were observed at 240 and $295^{\circ} \mathrm{C}$ (Balaji \& Nagarajan 2017). Compared to untreated and bleached treated fibres, bleached sample shows higher thermal stability. Through bleaching, the onset of thermal decomposition shifts to higher temperature due to removal of hemicellulose and lignin.

Based on Figure 4(b), bleached pepper pericarp (4C) was observed to have slightly higher degradation temperature at $332{ }^{\circ} \mathrm{C}$ as compared to other bleached pepper pericarp $\left(1 \mathrm{C}: 322{ }^{\circ} \mathrm{C}, 2 \mathrm{C}: 326{ }^{\circ} \mathrm{C} \& 3 \mathrm{C}: 329\right.$ ${ }^{\circ} \mathrm{C}$ ). Higher cycle numbers of bleaching treatment lead to an effective removal of lignin. The results obtained were in agreement with research conducted by $\mathrm{Ng}$ et al. (2014) that found cellulose obtained with 8 and $12 \mathrm{~h}$ of bleaching treatment had higher thermal stability than untreated sample.

Table 2 shows the weight loss of untreated pepper pericarp and bleached samples (1C, 2C, 3C, \& 4C). Higher cycle of bleaching treatment has lower weight loss as compared to other bleached samples. Lee et al. (2004) reported that the thermal decomposition of lignocellulosic components started with hemicellulose, then lignin, followed by depolymerisation of cellulose, active flaming combustion and char oxidation. Therefore, indicating high thermal stability of stronger bleached sample (low weight loss) as most of the hemicellulose and lignin has been effectively removed. 
TABLE 1. Whiteness index of untreated pepper pericarp, alkali treated and bleached sample

\begin{tabular}{lc}
\hline Samples & Whiteness index \\
\hline Untreated & $16.36 \pm 0.74^{\mathrm{d}}$ \\
Alkali treated & $-4.30 \pm 1.11^{\mathrm{e}}$ \\
Bleached 1C & $-8.93 \pm 0.52^{\mathrm{f}}$ \\
Bleached 2C & $46.05 \pm 0.92^{\mathrm{c}}$ \\
Bleached 3C & $70.39 \pm 0.94^{\mathrm{b}}$ \\
Bleached 4C & $77.00 \pm 1.10^{\mathrm{a}}$ \\
\hline a-f: Means with different alphabet are significantly different $(\mathrm{p}<0.05)$ &
\end{tabular}

TABLE 2. The weight loss of fibres

\begin{tabular}{lccccc}
\hline \multirow{2}{*}{ Samples } & \multicolumn{5}{c}{ Weight loss (\%) } \\
\cline { 2 - 6 } & $100{ }^{\circ} \mathrm{C}$ & $200{ }^{\circ} \mathrm{C}$ & $300{ }^{\circ} \mathrm{C}$ & $400{ }^{\circ} \mathrm{C}$ & $500{ }^{\circ} \mathrm{C}$ \\
\hline Raw pepper pericarp & 3.72 & 5.14 & 18.70 & 56.66 & 69.90 \\
Bleached sample - 1 cycle & 6.49 & 7.28 & 23.36 & 64.45 & 77.12 \\
Bleached sample - 2 cycle & 6.52 & 7.16 & 22.61 & 71.23 & 84.05 \\
Bleached sample - 3 cycle & 6.79 & 7.37 & 21.60 & 72.53 & 80.99 \\
Bleached sample - 4 cycle & 3.06 & 3.42 & 17.05 & 73.19 & 80.65 \\
\hline
\end{tabular}
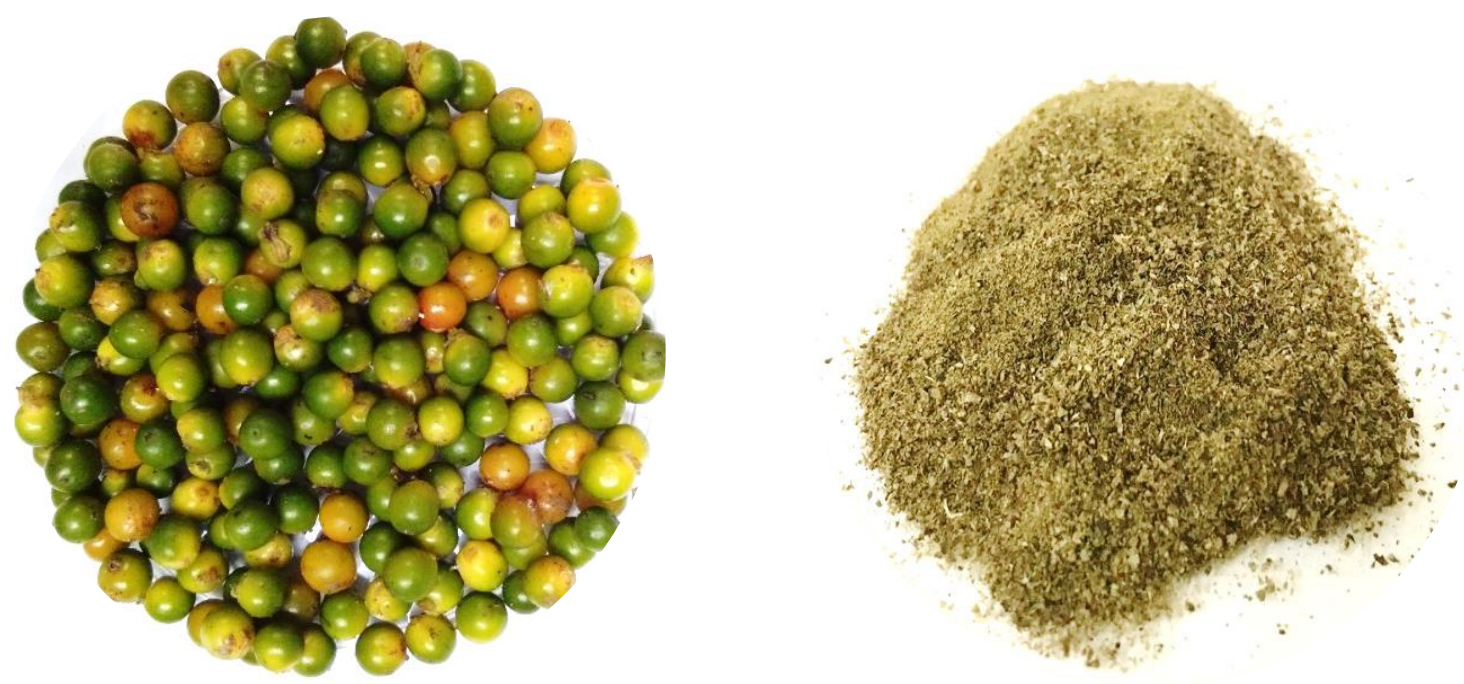

FIGURE 1. Photographs of (a) fresh green pepper berries and (b) untreated pepper pericarp 


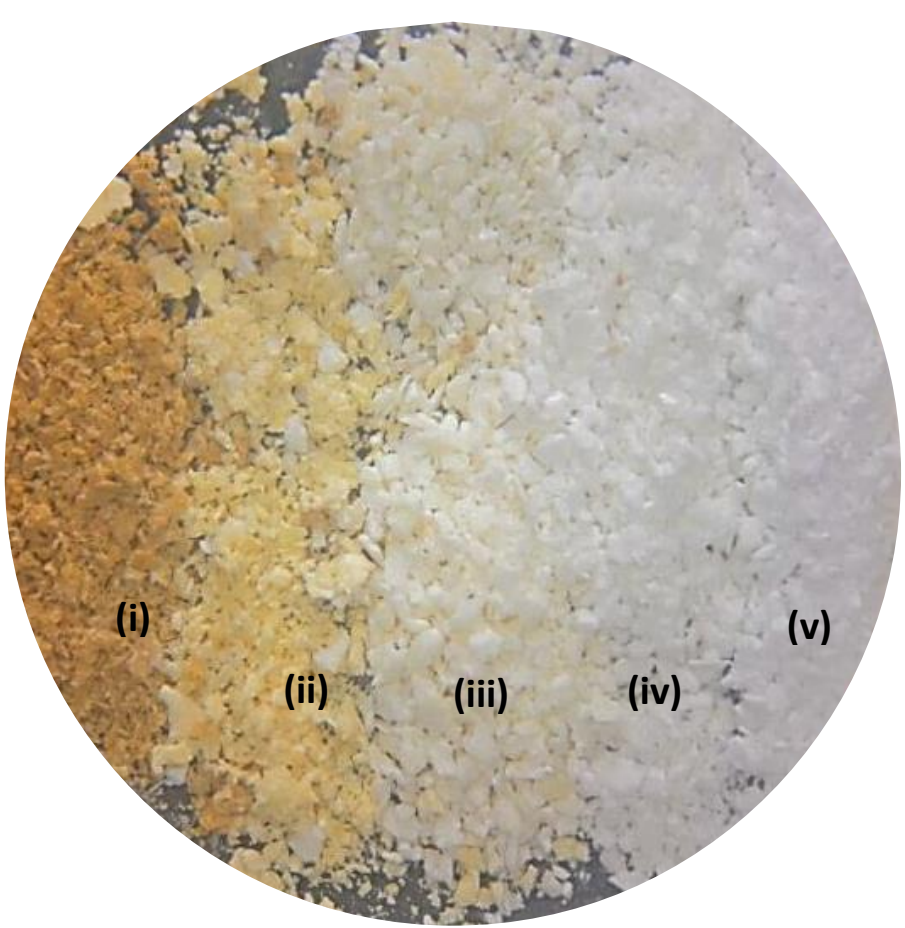

FIGURE 2. Optical microscopy of (i) alkali treated, (ii) $1 \mathrm{C}$ bleached treated, (iii) $2 \mathrm{C}$ bleached treated, (iv) $3 \mathrm{C}$ bleached treated, and (v) $4 \mathrm{C}$ bleached treated

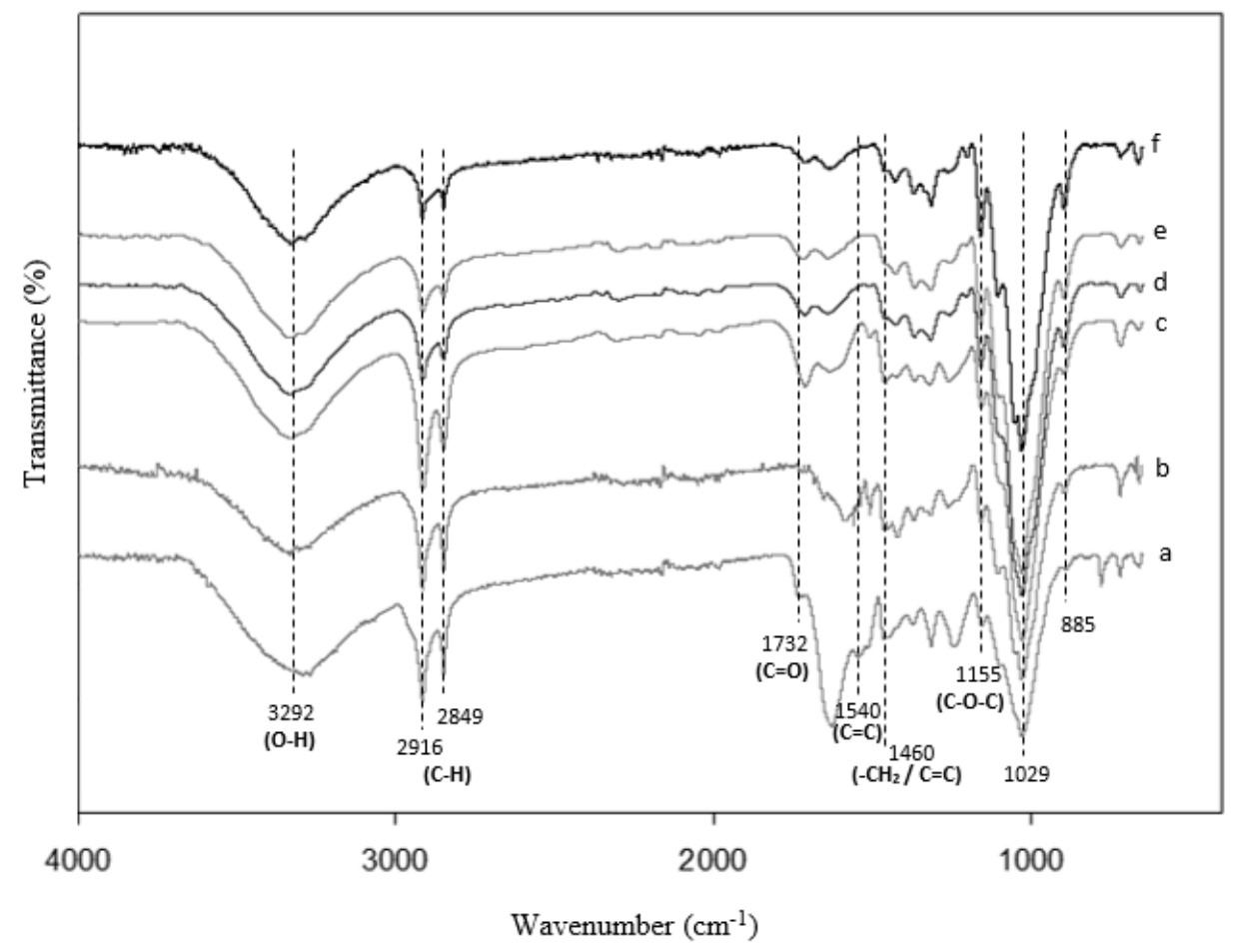

FIGURE 3. FTIR spectra recorded for (a) raw, (b) alkali treated, (c) 1C-bleached sample, (d) 2C-bleached sample, (e) 3C-bleached sample, \& (f) 4C-bleached sample 

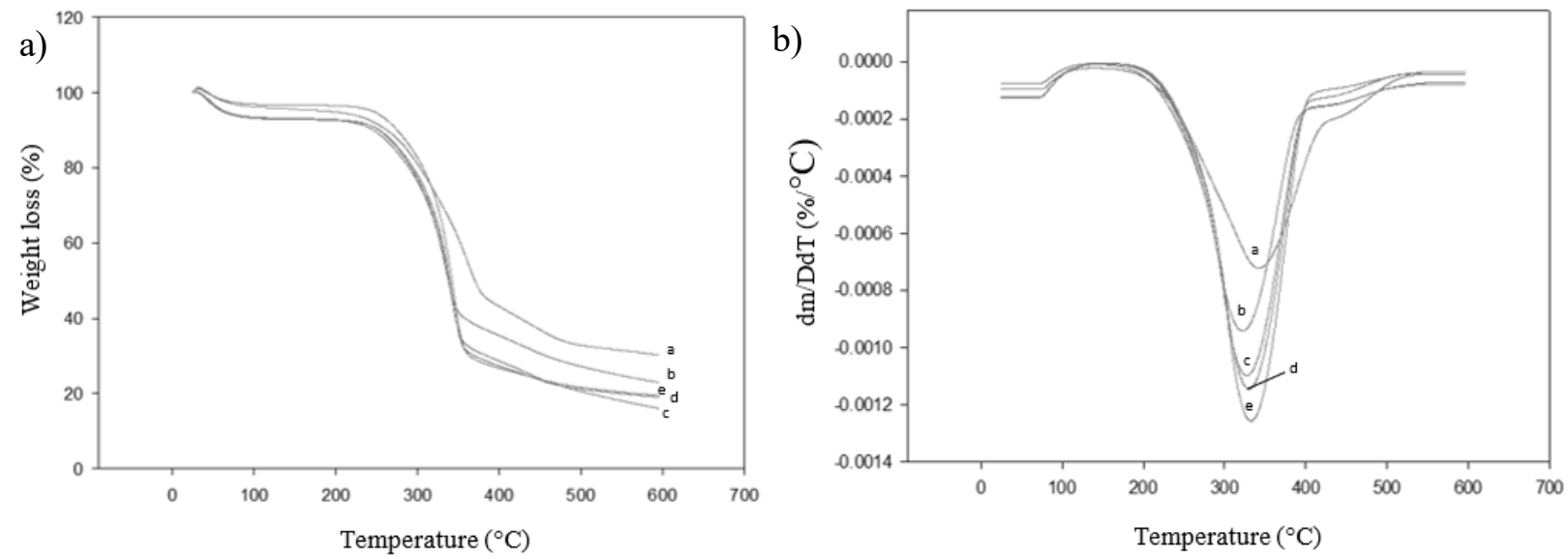

FIGURE 4. (a) \& (b) TGA and DTG thermogram for raw pepper pericarp (a) and bleached samples- 1C (b), 2C (c), 3C (d) and 4C (e)

\section{CONCLUSION}

Pepper pericarp waste was found to be an excellent source for production of cellulose. Combination of alkali and bleaching treatment seems to remove lignin and hemicellulose components successfully. The effect of preparation condition in terms of bleaching cycle, on the behaviour of cellulose was evaluated. Higher bleaching cycles produced whiter cellulose, with removal of most lignin and hemicellulose band in FTIR spectra and stable thermal properties. The optimum condition of bleaching treatment creates favourable changes towards chemical structure and thermal stability of cellulose produced.

\section{ACKNOWLEDGEMENTS}

The authors would like to acknowledge Universiti Kebangsaan Malaysia for funding this work under research grant GGPM-2017-065, as well as Department of Food Sciences, Faculty of Science and Technology UKM for the technical support and providing research facilities.

\section{REFERENCES}

Alemdar, A. \& Sain, M. 2008. Isolation and characterization of nanofibers from agricultural residues-wheat straw and soy hulls. Bioresource Technology 99(6): 1664-1671.

Balaji, A.N. \& Nagarajan, K.J. 2017. Characterization of alkali treated and untreated new cellulosic fiber from Saharan aloe vera cactus leaves. Carbohydrate Polymers 174: 200-208.

Bhandari, N.L., Mormann, W., Michler, G.H. \& Adhikari, R. 2013. Functionalisation of bamboo and sisal fibres cellulose in ionic liquids. Materials Research Innovations 17(4): 250-256.

Bharathiraja, S., Suriya, J., Krishnan, M., Manivasagan, P. \& Kim, S.K. 2017. Production of enzymes from agricultural wastes and their potential industrial applications. In Advances in Food and Nutrition Research, edited by Kim, S.K. \& Toldrá, F. Massachusetts: Academic Press. pp. 80: 125-148.
Bunchol, A.J. 2011. Interview with Food Technologist Officer Malaysian Pepper Board, Sarawak.

Color iQC and Color iMatch Color Calculations Guide. 2012. Version 8.0: 14.

Fathi, H.I., El-Shazly, A.H., Elkady, M.F. \& Madih, K. 2018. Assessment of new technique for production cellulose nanocrystals from agricultural waste. Materials Science Forum 928(August 2018): 83-88.

Henrique, M.A., Silvério, H.A., Neto, W.P.F. \& Pasquini, D. 2013. Valorization of an agro-industrial waste, mango seed, by the extraction and characterization of its cellulose nanocrystals. Journal of Environmental Management 121: 202-209.

Ilyas, R.A., Sapuan, S.M., Sanyang, M.L., Ishak, M.R. \& Zainudin, E.S. 2018. Nanocrystalline cellulose as reinforcement for polymeric matrix nanocomposites and its potential applications: A review. Current Analytical Chemistry 14(3): 203-225.

Johar, N., Ahmad, I. \& Dufresne, A. 2012. Extraction, preparation and characterization of cellulose fibers and nanocrystals from rice husk. Industrial Crops and Products 37(1): 93-99.

Jonoobi, M., Oladi, R., Davoudpour, Y., Oksman, K., Dufresne, A., Hamzeh, Y. \& Davoodi, R. 2015. Different preparation methods and properties of nanostructured cellulose from various natural resources and residues: A review. Cellulose 22(2): 935-969.

Jonoobi, M., Harun, J., Mishra, M. \& Oksman, K. 2009. Chemical composition, crystallinity and thermal degradation of bleached and unbleached kenaf bast (Hibiscus cannabinus) pulp and nanofibers. BioResources 4(2): 626-639.

Kalia, S., Dufresne, A., Cherian, B.M., Kaith, B.S., Avérous, L., Njuguna, J. \& Nassiopoulos, E. 2011. Cellulose-based bio- and nanocomposites: A review. International Journal of Polymer Science 2011: Article ID. 837875.

Kamarulzaman, N.H., Husin, H., Mohayidin, M.G. \& Enchi, J. 2013. Buyers' preferences among pepper farmers in Sarawak. Journal of Agribusiness Marketing 6: 1-13.

Karimi, S., Tahir, P.M., Karimi, A., Dufresne, A. \& Abdulkhani, A. 2014. Kenaf bast cellulosic fibers hierarchy: A comprehensive 
approach from micro to nano. Carbohydrate Polymers 101: 878-885.

Lee, H.L., Chen, G.C. \& Rowell, R.M. 2004. Thermal properties of wood reacted with a phosphorus pentoxide-amine system. Journal of Applied Polymer Science 91(4): 2465-2481.

Mandal, A. \& Chakrabarty, D. 2011. Isolation of nanocellulose from waste sugarcane bagasse (SCB) and its characterization. Carbohydrate Polymers 86(3): 1291-1299.

Mohd, N.H., Ismail, N.F.H., Zahari, J.I., Fathilah, W., Kargarzadeh, H., Ramli, S., Ahmad, I., Yarmo, M.A. \& Othaman, R. 2016. Effect of aminosilane modification on nanocrystalline cellulose properties. Journal of Nanomaterials 2016: Article ID. 4804271.

Mussatto, S.I., Ballesteros, L.F., Martins, S. \& Teixeira, J.A. 2012. Use of agro-Industrial wastes in solid-state fermentation processes. In Industrial Waste, edited by Show, K.Y. Rijeka: Intech. pp. 121-140.

Ng, T.S., Ching, Y.C., Awanis, N., Ishenny, N. \& Rahman, M.R. 2014. Effect of bleaching condition on thermal properties and UV transmittance of PVA/cellulose biocomposites. Materials Research Innovations 18(sup6): S6-400-S6-404.

Ngadi, N. \& Lani, N.S. 2014. Extraction and characterization of cellulose from empty fruit bunch (EFB) fiber. Jurnal Teknologi 68(5): 35-39.

Phanthong, P., Ma, Y., Guan, G. \& Abudula, A. 2015. Extraction of nanocellulose from raw apple stem. Journal of the Japan Institute of Energy 94(8): 787-793.

Reddy, J.P. \& Rhim, J.W. 2018. Extraction and characterization of cellulose microfibers from agricultural wastes of onion and garlic. Journal of Natural Fibers 15(4): 465-473.

Rosa, M.F., Medeiros, E.S., Malmonge, J.A., Gregorski, K.S., Wood, D.F., Mattoso, L.H.C., Glenn, G., Orts, W.J. \& Imam, S.H. 2010. Cellulose nanowhiskers from coconut husk fibers: Effect of preparation conditions on their thermal and morphological behavior. Carbohydrate Polymers 81(1): 83-92.

Sephton, P.S. 2011. Spatial arbitrage in Sarawak pepper prices. Canadian Journal of Agricultural Economics/Revue canadienne d'agroeconomie 59(3): 405-416.
Silva, M.C., Lopes, O.R., Colodette, J.L., Porto, A.O., Rieumont, J., Chaussy, D., Belgacem, M.N. \& Silva, G.G. 2008. Characterization of three non-product materials from a bleached eucalyptus kraft pulp mill, in view of valorising them as a source of cellulose fibres. Industrial Crops and Products 27(3): 288-295.

Yin, O.S., Ahmad, I. \& Amin, M.C.I.M. 2015. Effect of cellulose nanocrystals content and $\mathrm{pH}$ on swelling behaviour of gelatin based hydrogel. Sains Malaysiana 44(6): 793-799.

Zain, N.F.M., Yusop, M.S. \& Ahmad, I. 2014. Preparation and characterization of cellulose and nanocellulose from pomelo (Citrus grandis) albedo. Journal of Nutrition \& Food Sciences 5(1): 334.

Ain Nadiah Sofiah Ahmad Khorairi \& Noor Soffalina SofianSeng*

Department of Food Sciences

Faculty of Science and Technology

Universiti Kebangsaan Malaysia

43600 UKM Bangi, Selangor Darul Ehsan

Malaysia

Rizafizah Othaman

Department of Chemical Sciences

Faculty of Science and Technology

Universiti Kebangsaan Malaysia

43600 UKM Bangi, Selangor Darul Ehsan

Malaysia

Khairul Farihan Kasim

School of Bioprocess Engineering

Universiti Malaysia Perlis

01000 Kangar, Perlis Indera Kayangan

Malaysia

*Corresponding author; email: soffalina@ukm.edu.my

Received: 26 January 2020

Accepted: 8 April 2020 